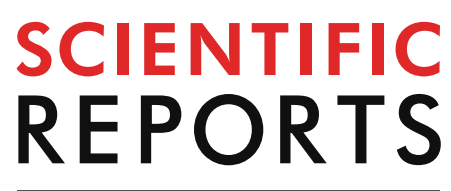

natureresearch

Check for updates

\title{
Optimised spectral effects of programmable LED arrays (PLA)s on bioelectricity generation from algal-biophotovoltaic devices
}

\author{
Fong-Lee $\mathrm{Ng}^{1}$, Siew-Moi Phang ${ }^{1,2 \bowtie}$, Boon Leong Lan ${ }^{3}$, Vineetha Kalavally ${ }^{3}$, \\ Cheng-Han Thong ${ }^{1,4}$, Kian-Ted Chong ${ }^{1}$, Vengadesh Periasamy ${ }^{5}$, \\ Karthikeyan Chandrasekaran ${ }^{1}$, G. Gnana kumar ${ }^{6}$, Kamran Yunus ${ }^{7}$ \& Adrian C. Fisher
}

The biophotovoltaic cell (BPV) is deemed to be a potent green energy device as it demonstrates the generation of renewable energy from microalgae; however, inadequate electron generation from microalgae is a significant impediment for functional employment of these cells. The photosynthetic process is not only affected by the temperature, $\mathrm{CO}_{2}$ concentration and light intensity but also the spectrum of light. Thus, a detailed understanding of the influences of light spectrum is essential. Accordingly, we developed spectrally optimized light using programmable LED arrays (PLA)s to study the effect on algae growth and bioelectricity generation. Chlorella is a green microalga and contains chlorophyll- $a$ (chl-a), which is the major light harvesting pigment that absorbs light in the blue and red spectrum. In this study, Chlorella is grown under a PLA which can optimally simulate the absorption spectrum of the pigments in Chlorella. This experiment investigated the growth, photosynthetic performance and bioelectricity generation of Chlorella when exposed to an optimally-tuned light spectrum. The algal BPV performed better under PLA with a peak power output of $0.581 \mathrm{~mW} \mathrm{~m}^{-2}$ for immobilized BPV device on day 8 , which is an increase of $188 \%$ compared to operation under a conventional white LED light source. The photosynthetic performance, as measured using pulse amplitude modulation (PAM) fluorometry, showed that the optimized spectrum from the PLA gave an increase of $72 \%$ in the rETRmax value $\left(190.5 \mu \mathrm{mol}\right.$ electrons $\left.\mathrm{m}^{-2} \mathrm{~s}^{-1}\right)$, compared with the conventional white light source. Highest algal biomass $\left(1100 \mathrm{mg} \mathrm{L}^{-1}\right)$ was achieved in the immobilized system on day eight, which translates to a carbon fixation of $550 \mathrm{mg}$ carbon $\mathrm{L}^{-1}$. When artificial light is used for the BPV system, it should be optimized with the light spectrum and intensity best suited to the absorption capability of the pigments in the cells. Optimum artificial light source with algal BPV device can be integrated into a power management system for low power application (eg. environment sensor for indoor agriculture system).

Algae are being used in the development of biophotovoltaic devices (BPVs) for bioelectricity generation ${ }^{1}$. During photosynthesis, radiant energy absorbed by the algal cell drives the splitting of water to release a pair of electrons, which can be transported to the anode in the BPV device, and then to the cathode via an external circuit ${ }^{2}$. Ng et al. ${ }^{3}$ proved the formation of charge-transfer complex between algal biofilms, anode electrode and cathode electrode by measuring surface potential energy of different electrodes using the Kelvin probe method. Smaller gap in surface potential, higher electron donor/acceptor capacity and lower electrical resistivity of electrode

${ }^{1}$ Institute of Ocean and Earth Sciences (IOES), University of Malaya, Kuala Lumpur, Malaysia. ${ }^{2}$ Faculty of Applied Sciences, UCSI University, Kuala Lumpur, Malaysia. ${ }^{3}$ Electrical and Computer Systems Engineering and Advanced Engineering Platform, School of Engineering, Monash University, Sunway, Malaysia. ${ }^{4}$ Institute for Advanced Studies, University of Malaya, Kuala Lumpur, Malaysia. ' ${ }^{5}$ ow Dimensional Materials Research Centre (LDMRC), Department of Physics, University of Malaya, Kuala Lumpur, Malaysia. ${ }^{6}$ Department of Physical Chemistry, School of Chemistry, Madurai Kamaraj University, Madurai, Tamil Nadu 625021, India. ${ }^{7}$ Department of Chemical Engineering and Biotechnology, University of Cambridge, Philipa Fawcett Drive, Cambridge CB3 OAS, UK. ${ }^{\square}$ email: phang@um.edu.my 
contributed to higher power generation. Electron transfer can be direct, through endogenous mediators (eg. flavin), or through exogenous mediators (eg. polypyrrole), but direct electron transfer is preferable due to economy of cost and effort ${ }^{4}$. $\mathrm{TiO}_{2}$ nanowires ${ }^{5}$ and trimetallic Pt based $\left(\mathrm{PtAuCu}\right.$ ) alloy nanowires ${ }^{6}$, which exhibit significant electrocatalytic performance, high specific surface area, good biocompatibility, are able to improve fuel cell's performance. Besides, nano-composite catalyst showed promising results: Kodali et al. ${ }^{7}$ enhanced the MFC performance by using an iron-graphence catalyst and Karthikeyan et al. ${ }^{8}$ reported 3D flower-like $\mathrm{FeWO}_{4} / \mathrm{CeO}_{2}$ on rGO produced high power and stable power output from alga BPV devices. BPV devices have been reported to generate current and power densities, respectively, in the range of 0.17 to $993 \mathrm{~mA} \mathrm{~m}^{-2}$ and up to $400 \mathrm{~mW} \mathrm{~m}^{-2}$ with various BPV reactors and operating parameters ${ }^{1}$. The maximum power density reported thus far was generated from a two-chamber device using an algae suspension, mediated electron transfer, and a gold-inscribed Nafion membrane ${ }^{9}$. However, the selection of algal strains with high photosynthetic performance, and providing these living energy-conversion microbes with the most suitable physiological conditions to perform their activities optimally is very important. Studies of improvised algal BPV systems were carried out to increase the power output from algal BPV devices ${ }^{10-12}$. However, the algal BPV has another important advantage over the MFC: while the MFC releases $\mathrm{CO}_{2}$, the algal BPV device consumes $\mathrm{CO}_{2}$ and releases $\mathrm{O}_{2}$. Therefore, the carbon negative algal BPV device represents a sustainable, environment-friendly technology amenable to low-power applications.

Irradiance, characterized by both quality and quantity, is a critical factor influencing photosynthetic performance ${ }^{13}$. Algal cells use a fraction $(0.1 \%)$ of the radiant energy that is absorbed by chl- $a$ in the chloroplast, for photosynthesis. Excess energy is dissipated as fluorescence and heat ${ }^{14}$, accompanied by a defense mechanism that triggers production of reactive oxygen species (ROS) to prevent photo-oxidative damage to the Photosystem II (PS II) in a process known as photoinhibition, which ultimately prevents cellular death ${ }^{15}$. In dense cultures, while photoinhibition may occur at the upper layer, cells in the lower layers may be light-deprived due to light attenuation as it penetrates the culture ${ }^{15}$, resulting in reduced biomass production ${ }^{16}$. Continuous exposure to high irradiance further damages the PS II apparatus which leads to buildup of these impaired units and failure in maintaining charge separation within the photosystem ${ }^{17}$.

A considerable amount of literature has been published on the effect of radiant spectrum and energy on photosynthesis, pigmentation and algal biomass production. Plants including algae use visible light, ranging from 400 to $700 \mathrm{~nm}$, known as the photosynthetically active radiation (PAR) region, which are wavelengths with sufficient energy to support the photosynthetic process ${ }^{18}$. However, blue $(420-450 \mathrm{~nm})$ and red $(660-700 \mathrm{~nm})$ light are known to be as efficient for photosynthesis as the full spectrum. Chlorophylls, carotenoids and phycobilins comprise the pigments found in algae. Chlorophyl- $a(\mathrm{chl}-a)$ is the main pigment responsible for energy absorption while chlorophyll $b, c$ and carotenoids are accessory pigments, with the latter performing photoprotection roles as well. The composition of pigments in algae defines the irradiance spectrum best suited for its photosynthetic performance. This is especially relevant when artificial light is used for cultivation. The Chlorophytes, or green algae, with chlorophylls being the dominant pigments, absorb mainly blue and red light. Chlorophytes are able to utilize blue light more efficiently than cyanobacteria, due to the loss of chl- $b$ in cyanobacterial species ${ }^{19}$.

Photosynthesis in microalgae can be driven by sunlight or artificial light. Although sunlight is the most costeffective energy source for microalgae production, consistent artificial lighting is still economically feasible when biomass is used as a feedstock for high value product such as food supplements ${ }^{20}$. LED light is an emerging and economical technology compared to ordinary fluorescent lamps in microalgal production because of its lower power consumption, longer life time, lower heat dissipation, smaller mass and volume, generation of lower heat when supplying light, longer life-span compared to fluorescence lamp, and higher conversion efficiency ${ }^{21}$. Green LEDs $(525-550 \mathrm{~nm}$ ) were often found to be unsuitable for microalgae culture if used without additional light source. Mixing of red and blue photons (red LEDs supplemented with 10 to $30 \%$ blue light) has often increased biomass production compared to red light alone ${ }^{20}$.

Intensive research efforts have been focused on how to achieve maximum growth of microalgae. One of the promising strategies is to provide a light source in which the irradiance spectrum is specifically tailored to the absorption spectrum of the light harvesting pigments. Sforza et al. ${ }^{22}$ reported improved growth rate of Nannochloropsis salina in photobioreactor using a white LED with a spectrum ranging from 400 to $780 \mathrm{~nm}$. Maximum growth rate occurred with $150 \mu \mathrm{mol}$ photons $\mathrm{m}^{-2} \mathrm{~s}^{-1}$ at $0.521 \mathrm{day}^{-122}$. Das et al. ${ }^{23}$ reported that Nanochloropsis sp. registered highest specific growth rate at 0.64 day $^{-1}$ under blue light ${ }^{23}$. Mohsenpour and Willoughby ${ }^{24}$ presented growth of Chlorella vulgaris (Chlorophyte) and Gloeothece membranacea (Cyanophyte) under different light conditions. Results indicated that red light enhanced biomass production for both the strains, $0.135 \mathrm{gL}^{-1} \mathrm{day}^{-1}$ and $0.184 \mathrm{gL}^{-1} \mathrm{day}^{-1}$ for Chlorella vulgaris and Gloeothece membranacea respectively. Green light increased chlorophyll production in Chlorella vulgaris with an increase of $1.98 \% \mathrm{~g} / \mathrm{g}$ cell $)^{25}$. However, there is a lack of research concerning the effect of improved light quality on bioelectricity generation. In this study, the absorption spectrum of the chlorophyte Chlorella UMACC 313 was determined and used as the reference to provide irradiance through the programmable LED arrays (PLA)s. Chlorella sp. was investigated under two types of irradiance; the PLA based on the absorption spectrum of the Chlorella (treatment), and white LED light (control) to study the effectiveness of light quality on biomass production, photosynthetic performance, and bioelectricity generation.

\section{Results and discussion}

BPV devices, containing either immobilized algae or suspended algae, were exposed to conventional white LED light, at $90 \mu \mathrm{mol}$ photons $\mathrm{m}^{-2} \mathrm{~s}^{-1}$, and $25 \pm 2{ }^{\circ} \mathrm{C}$ as a control. The treatment was exposure to light from the PLA using the simulated absorption spectrum of the Chlorella pigments. Light exposure was provided on a $12 \mathrm{~h}: 12 \mathrm{~h}$ light:dark cycle in an incubator maintained at $25 \pm 2{ }^{\circ} \mathrm{C}$. Each condition was repeated in triplicate. Cultures were grown for 12 days, with measurements for growth, photosynthetic performance and power output taken on days 


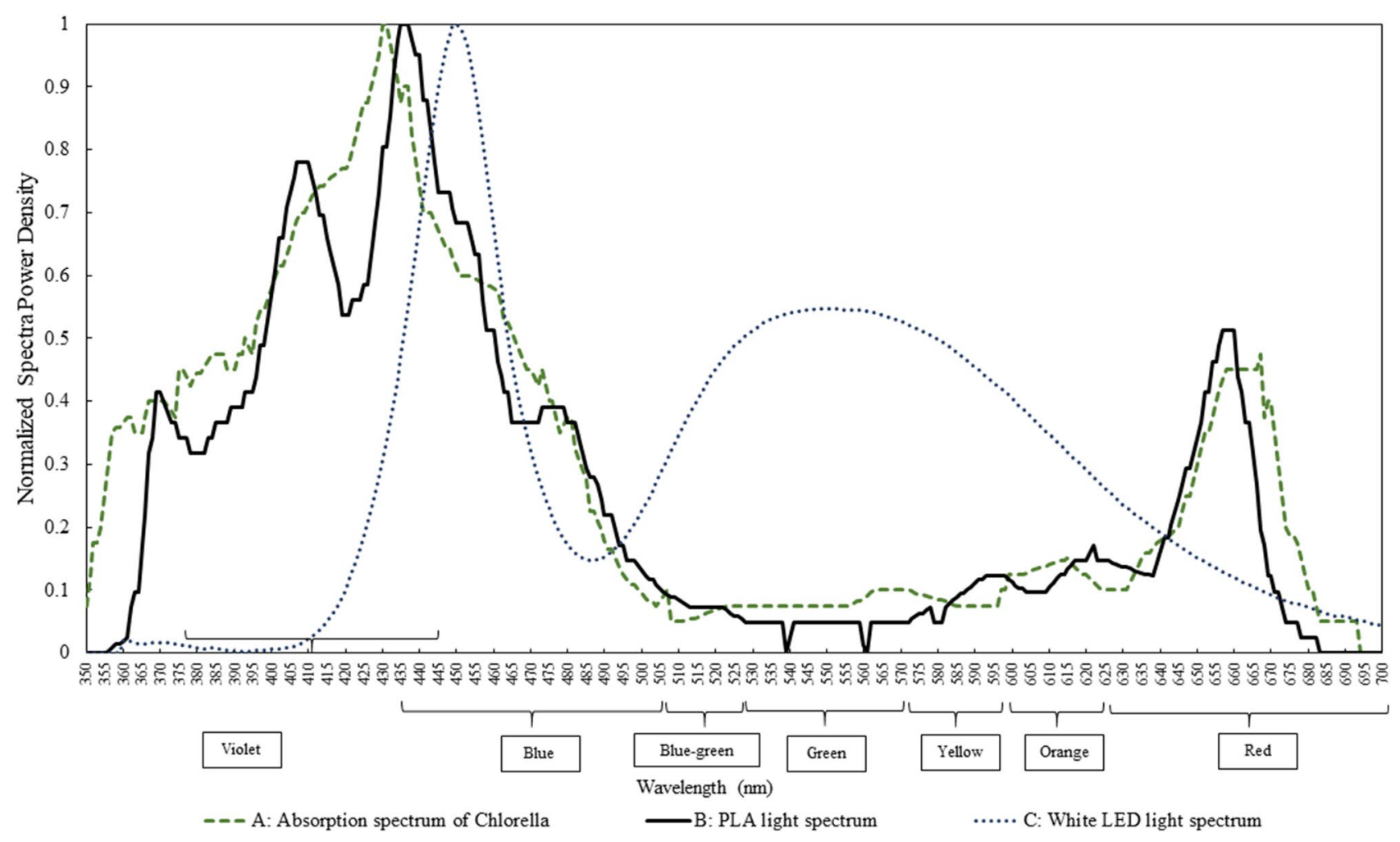

Figure 1. Comparison of three different spectra. (A) Measured absorption spectrum of Chlorella UMACC 313 (based on the extracted chl- $a$ and carotenoid pigments), (B) simulated absorption spectrum of Chlorella UMACC 313 produced by the PLA, (C) spectrum of conventional LED white light.

$0,4,8$, and 12 . Power output measurements were taken during light and dark conditions, to determine if current (dark current) is also generated in the dark ${ }^{11}$.

Absorption spectrum of chlorophylls and carotenoids from Chlorella UMACC 313 . The measured absorption spectrum of the pigments (chlorophylls and carotenoids) from Chlorella UMACC 313 is compared with the spectrum of the white LED light, and the simulated absorption spectrum of the Chlorella pigments generated by the PLA (Fig. 1).

There was good compatibility between the measured and simulated absorption spectrum of the pigments. Emission spectrum of simulated illumination produced by the PLA corresponded very closely to absorption spectrum of Chlorella UMACC 313, including the spectral region absorbed by the chl- $a$ and carotenoid pigments (wavelength peaks at 370, 410, 435 and $660 \mathrm{~nm}$ ). Although the white light spectrum, with wavelength peaks at 450 and $560 \mathrm{~nm}$, did not compare very well with the other two spectra, there was sufficient overlap with the measured absorption spectrum of Chlorella UMACC 313 to allow use of white light for algal culture.

Growth of Chlorella UMACC 313 in the algal BPV devices. Table 1 gives details of the cell density along with chl- $a$ and carotenoid content of the algae grown in the BPV with immobilized and suspended algae, under control (exposure to conventional white LED light) and treatment (exposure to light from the PLA) conditions on days $0,4,8$, and 12 . The specific growth rates, $\mu$, based on chl- $a$ and calculated from day 4 to day 8 (exponential phase) of the cultures, were $0.57 \mathrm{day}^{-1}$ and $0.85 \mathrm{day}^{-1}$ under control condition, and $0.82 \mathrm{day}^{-1}$ and 0.92 day $^{-1}$ under treatment conditions for the suspended and immobilized cultures, respectively. Growth rate and cells density of microalgae were higher in immobilized cultures. In alginate, carboxylic groups are naturally present and randomly distributed, and some monomeric units may have more than one carboxylic group ${ }^{26}$. This may contribute to better contact between the microalgae cells and ITO anode in this study. The immobilized algae grow faster when immobilized inside the harmless and non-toxic alginate gel, where nutrients from the medium freely diffuse through the porous gel. Our data showing slower growth of cells in the immobilized condition from day 0 to day 4 supports an interpretation that it took time for these cells to acclimatize to the physical change of environmental conditions compared to suspended cells ${ }^{11}$. However, once the cells had adapted to being encapsulated within the alginate gel matrix, cell density increased rapidly for the remainder of the experiment, from day 4 through day 12 .

Microalgae reproduction capacity depends on the characteristic of the light wavelength ${ }^{27}$. In this study, higher growth rate was observed when the algal cells were grown in the simulated spectrum that was close to the absorption spectrum of the pigments of Chlorella UMACC 313. Specifically, when the BPVs were exposed to treatment conditions, growth rates determined based on chl- $a$ increased by $43.9 \%$ for suspended and $12.2 \%$ 


\begin{tabular}{|c|c|c|c|c|c|}
\hline Light source & Day & Culture condition & Cell density $\left(\times 10^{7}\right.$ cells $\left.\mathrm{mL}^{-1}\right)$ & Chl- $a\left(\mathrm{mg} \mathrm{L}^{-1}\right)$ & Carotenoids $\left(\mathrm{mg} \mathrm{L}^{-1}\right)$ \\
\hline \multirow{8}{*}{$\begin{array}{l}\text { Conventional white LED light } \\
90 \mu \mathrm{mol} \text { photons } \mathrm{m}^{-2} \mathrm{~s}^{-1}\end{array}$} & \multirow{2}{*}{0} & Suspended & $3.67 \pm 0.76^{\mathrm{cd}}$ & $0.129 \pm 0.008^{f}$ & $0.073 \pm 0.010^{\mathrm{e}}$ \\
\hline & & Immobilized & $5.17 \pm 0.29^{\mathrm{cd}}$ & $0.362 \pm 0.040^{\mathrm{f}}$ & $0.150 \pm 0.020^{\mathrm{de}}$ \\
\hline & \multirow{2}{*}{4} & Suspended & $9.5 \pm 1.8^{\text {cd }}$ & $1.28 \pm 0.14^{\mathrm{e}}$ & $0.523 \pm 0.068^{\mathrm{de}}$ \\
\hline & & Immobilized & $17 \pm 1^{\text {cd }}$ & $10.80 \pm 0.33^{b}$ & $5.781 \pm 0.002^{b}$ \\
\hline & \multirow{2}{*}{8} & Suspended & $38.3 \pm 3.8^{\mathrm{bc}}$ & $4.53 \pm 0.60^{\mathrm{d}}$ & $1.58 \pm 0.15^{\mathrm{d}}$ \\
\hline & & Immobilized & $98 \pm 5^{\mathrm{b}}$ & $13.23 \pm 0.34^{\mathrm{b}}$ & $8.1 \pm 1.0^{\mathrm{a}}$ \\
\hline & \multirow{2}{*}{12} & Suspended & $50 . \pm 5^{\mathrm{b}}$ & $2.89 \pm 0.18^{\mathrm{e}}$ & $1.03 \pm 0.16^{\mathrm{de}}$ \\
\hline & & Immobilized & $145 \pm 19^{\mathrm{a}}$ & $9.79 \pm 0.72^{c}$ & $4.82 \pm 0.24^{\mathrm{bc}}$ \\
\hline \multirow{8}{*}{$\begin{array}{l}\text { PLA } \\
90 \mu \mathrm{mol} \text { photons } \mathrm{m}^{-2} \mathrm{~s}^{-1}\end{array}$} & \multirow{2}{*}{0} & Suspended & $2.17 \pm 0.29^{\mathrm{d}}$ & $0.141 \pm 0.012^{\mathrm{f}}$ & $0.100 \pm 0.009^{e}$ \\
\hline & & Immobilized & $3.5 \pm 0.5^{\mathrm{cd}}$ & $0.390 \pm 0.045^{\mathrm{f}}$ & $0.223 \pm 0.027^{\mathrm{de}}$ \\
\hline & \multirow{2}{*}{4} & Suspended & $12.5 \pm 2.5^{\mathrm{cd}}$ & $3.72 \pm 0.25^{\mathrm{de}}$ & $1.100 \pm 0.071^{\mathrm{d}}$ \\
\hline & & Immobilized & $10.3 \pm 1.5^{\mathrm{cd}}$ & $15.52 \pm 0.45^{\mathrm{a}}$ & $6.37 \pm 0.47^{\mathrm{ab}}$ \\
\hline & \multirow{2}{*}{8} & Suspended & $26.7 \pm 3.8^{c}$ & $7.54 \pm 0.42^{c}$ & $2.69 \pm 0.23^{c}$ \\
\hline & & Immobilized & $223 \pm 19^{\mathrm{a}}$ & $16.42 \pm 0.23^{\mathrm{a}}$ & $7.00 \pm 0.13^{\mathrm{a}}$ \\
\hline & \multirow{2}{*}{12} & Suspended & $53.3 \pm 7.6^{\mathrm{b}}$ & $5.41 \pm 0.11^{\mathrm{d}}$ & $1.97 \pm 0.19^{\mathrm{cd}}$ \\
\hline & & Immobilized & $164.2 \pm 6.7^{\mathrm{a}}$ & $7.22 \pm 0.16^{\mathrm{c}}$ & $4.69 \pm 0.39^{c}$ \\
\hline
\end{tabular}

Table 1. Statistical comparison of cell density $\left(\times 10^{7}\right.$ cells $\left.\mathrm{mL}^{-1}\right)$, chl- $a$ concentration $\left(\mathrm{mg} \mathrm{L}^{-1}\right)$ and carotenoid concentration $\left(\mathrm{mg} \mathrm{L}^{-1}\right)$ in algal-biophotovoltaic device with suspended and immobilized of Chlorella UMACC 313 under conventional white LED light or PLA on days $0,4,8$, and 12 . Data as means \pm S.D. $(n=3)$. Different letters indicate significant different between different value (ANOVA, Tukeýs HSD test, $\mathrm{p}<0.05$ ).

for immobilized cultures compared to the control condition. The lower percent increase in immobilized cultures might be due to an increase in cell density within the alginate film that caused self-shading and/or a decrease in nutrient diffusion efficiency that limited cell growth and led to lower power output.

Generally, pigment contents (chl- $a$ and carotenoid) in immobilized algae were observed to be higher compared to suspended algae cultures. Higher chl- $a$ content occurred on day $4\left(15.52 \mathrm{mg} \mathrm{L}^{-1}\right)$ and day $8(16.42 \mathrm{mg}$ $\left.\mathrm{L}^{-1}\right)$ compared to day $0\left(0.390 \mathrm{mg} \mathrm{L}^{-1}\right)$ and day $12\left(7.22 \mathrm{mg} \mathrm{L}^{-1}\right)$ under treatment conditions. Higher chl- $a$ content in immobilized state on day 4 and day 8 may be due to the high irradiance to the thin layer of gel film that led to high physiological activities of the algal cells. However chl- $a$ content decreased on day $12\left(7.22 \mathrm{mg} \mathrm{L}^{-1}\right)$, which may be due to nutrient limitation and $\mathrm{CO}_{2}$ diffusion limitation occurring in the immobilized cells because of high cell density inside the alginate films and relative to lower power density $\left(0.332 \mathrm{~mW} \mathrm{~m}^{-2}\right)$ compared to day $8\left(0.451 \mathrm{~mW} \mathrm{~m}^{-2}\right)^{28}$.

The highest carotenoid content was observed on day $8\left(8.1 \mathrm{mg} \mathrm{L}^{-1}\right)$ when the immobilized Chlorella cells were exposed to control conditions, followed by Chlorella cells in immobilized state exposed to treatment conditions $\left(7.00 \mathrm{mg} \mathrm{L}^{-1}\right)$. This high amount of carotenoid content may represent a protective response to environmental stress and low photosynthetic efficiency of the cells $(\alpha=0.558)$. In this study, high cell density and limited nutrients were observed on day 8 and likely caused algae cells to accumulate carotenoids to preserve cells from oxidative damage by reducing photosynthetic activity metabolic rate. Reduction of photosynthetic electrons transport may be associated with the formation of free radicals and singlet oxygen. In order to prevent damage from photooxidation, microalgae are able to synthesize a large amount of carotenoids, which can deactivate these dangerous oxidant molecules ${ }^{29}$.

Carbon fixation in the algal BPV devices was computed on day 8. Under the control light source, carbon fixation by suspended and immobilized algal cells, was 150 and $440 \mathrm{mg}$ carbon $\mathrm{L}^{-1}$, respectively. Under the treatment light source, carbon fixation by suspended and immobilized algal cells was 250 and $550 \mathrm{mg}$ carbon $\mathrm{L}^{-1}$, respectively. Under the control light source, $\mathrm{CO}_{2}$ fixation rate was found to be 57 and $123 \mathrm{mg} \mathrm{CO}_{2} \mathrm{~L}^{-1}$ day $^{-1}$ for the suspended and immobilized algae, respectively. Under the treatment light source, $\mathrm{CO}_{2}$ fixation rate was 68 and $198 \mathrm{mg} \mathrm{CO}_{2} \mathrm{~L}^{-1}$ day $^{-1}$ for the suspended and immobilized algae, respectively. During photosynthesis, $\mathrm{CO}_{2}$ is utilized in the Calvin-Benson Cycle through regulation of the enzyme ribulose bisphosphate carboxylase-oxygenase (Rubisco); a declining Rubisco level induces higher $\mathrm{CO}_{2}$ uptake. The enzyme carbonic anhydrase (CA) will respond to different conditions. If necessary, it will convert bicarbonate, $\mathrm{HCO}_{3}{ }^{-}$, to $\mathrm{CO}_{2}$ for Rubisco-driven metabolic activities. Hence, the regulation of Rubisco activity is dependent on light source and directly affects the carbon fixation rate by microalgae $e^{30,31}$. This explains why carbon and $\mathrm{CO}_{2}$ fixation rates were higher under the treatment light source for both suspended and immobilized cultures. Under the treatment light source, Chlorella cells showed better photosynthetic performances, with high Alpha and rETRmax values and improved efficiency of the carbon fixation process. All these values are based on small BPV devices; for future work, modules of the device will be stacked to increase the power output.

Temperature, $\mathrm{pH}$, nutrients and light quality (wavelength) are responsible for intensifying the $\mathrm{CO}_{2}$-conversion in algal cells. Captured carbon from atmosphere is pumped by bicarbonate transporters present in plasma membrane and chloroplast in algal cells. Bicarbonate is converted into $\mathrm{CO}_{2}$ that can be fixed by rubisco (ribulose bisphosphate carboxylase oxygenase) inside the chloroplast to produce two molecules of 3-phosphoglycerate. Three carbon organic acids are then reduced to the sugars for starch and lipid production. Oxygen can compete 


\begin{tabular}{|c|c|c|c|c|c|c|}
\hline Light source & Day & Culture condition & $\mathrm{Fv} / \mathrm{Fm}$ & Alpha ( $(\alpha)$ & $\begin{array}{l}\text { rETRmax }(\mu \mathrm{mol} \\
\left.\text { electrons } \mathbf{m}^{-2} \mathbf{s}^{-1}\right)\end{array}$ & $\begin{array}{l}\text { Ek ( } \mu \text { mol photons } \\
\left.\mathbf{m}^{-2} \mathbf{s}^{-1}\right)\end{array}$ \\
\hline \multirow{8}{*}{$\begin{array}{l}\text { Conventional White } \\
\text { LED Light } \\
90 \mu \text { mol photons } \\
\mathrm{m}^{-2} \mathrm{~s}^{-1}\end{array}$} & \multirow{2}{*}{0} & Suspended & $0.226 \pm 0.018^{\text {ef }}$ & $0.246 \pm 0.042^{\mathrm{g}}$ & $39.7 \pm 3.3^{\text {gh }}$ & $164 \pm 30^{\text {cde }}$ \\
\hline & & Immobilized & $0.317 \pm 0.042^{\text {ef }}$ & $0.422 \pm 0.015^{\mathrm{ef}}$ & $24.2 \pm 3.7^{\mathrm{h}}$ & $57.2 \pm 7.4^{\mathrm{h}}$ \\
\hline & \multirow{2}{*}{4} & Suspended & $0.476 \pm 0.055^{\mathrm{ed}}$ & $0.539 \pm 0.041^{\text {cde }}$ & $69.1 \pm 1.3^{\text {def }}$ & $129 \pm 12^{\text {efg }}$ \\
\hline & & Immobilized & $0.517 \pm 0.022^{\mathrm{bc}}$ & $0.596 \pm 0.048^{\mathrm{cd}}$ & $58.3 \pm 3.5^{\text {defg }}$ & $99 \pm 13^{\mathrm{gh}}$ \\
\hline & \multirow{2}{*}{8} & Suspended & $0.693 \pm 0.013^{\mathrm{a}}$ & $0.559 \pm 0.048^{\text {cde }}$ & $125.2 \pm 6.9^{c}$ & $224.3 \pm 6.8^{\mathrm{bc}}$ \\
\hline & & Immobilized & $0.647 \pm 0.066^{\mathrm{ab}}$ & $0.558 \pm 0.028^{\text {cde }}$ & $110.5 \pm 3.9^{c}$ & $198 \pm 15^{\mathrm{bcd}}$ \\
\hline & \multirow{2}{*}{12} & Suspended & $0.705 \pm 0.016^{\mathrm{a}}$ & $0.614 \pm 0.055^{\mathrm{c}}$ & $52.11 \pm 0.26^{\mathrm{fg}}$ & $85.2 \pm 7.1^{\mathrm{gh}}$ \\
\hline & & Immobilized & $0.697 \pm 0.026^{\mathrm{a}}$ & $0.552 \pm 0.015^{\text {cde }}$ & $56.4 \pm 4.2^{\mathrm{efg}}$ & $102.1 \pm 8.0^{\mathrm{fgh}}$ \\
\hline \multirow{8}{*}{$\begin{array}{l}\text { PLA } \\
90 \mu \text { mol photons } \\
\mathrm{m}^{-2} \mathrm{~s}^{-1}\end{array}$} & \multirow{2}{*}{0} & Suspended & $0.196 \pm 0.023^{\mathrm{f}}$ & $0.358 \pm 0.014^{\mathrm{fg}}$ & $38.368 \pm 0.010^{\text {gh }}$ & $107.4 \pm 4.1^{\text {efgh }}$ \\
\hline & & Immobilized & $0.348 \pm 0.005^{\mathrm{de}}$ & $0.451 \pm 0.014^{\text {def }}$ & $41.4 \pm 2.8^{\text {gh }}$ & $91.8 \pm 5.1^{\mathrm{gh}}$ \\
\hline & \multirow{2}{*}{4} & Suspended & $0.523 \pm 0.067^{\mathrm{bc}}$ & $0.599 \pm 0.060^{\text {cd }}$ & $254 \pm 15^{\mathrm{a}}$ & $427 \pm 54^{\mathrm{a}}$ \\
\hline & & Immobilized & $0.516 \pm 0.061^{\mathrm{bc}}$ & $0.372 \pm 0.065^{\mathrm{fg}}$ & $76 \pm 15^{\mathrm{de}}$ & $203.2 \pm 4.8^{\mathrm{bcd}}$ \\
\hline & \multirow{2}{*}{8} & Suspended & $0.601 \pm 0.045^{\mathrm{abc}}$ & $0.794 \pm 0.069^{\mathrm{ab}}$ & $126 \pm 18^{c}$ & $160 \pm 30^{\text {def }}$ \\
\hline & & Immobilized & $0.631 \pm 0.011^{\mathrm{ab}}$ & $0.844 \pm 0.090^{\mathrm{a}}$ & $190.5 \pm 5.4^{\mathrm{b}}$ & $277 \pm 20^{\mathrm{b}}$ \\
\hline & \multirow{2}{*}{12} & Suspended & $0.589 \pm 0.035^{\mathrm{abc}}$ & $0.618 \pm 0.079^{c}$ & $130.1 \pm 6.9^{c}$ & $212 \pm 21^{\mathrm{bcd}}$ \\
\hline & & Immobilized & $0.611 \pm 0.025^{\mathrm{abc}}$ & $0.642 \pm 0.054^{\mathrm{bc}}$ & $81.8 \pm 4.4^{\mathrm{d}}$ & $127.7 \pm 5.2^{\mathrm{efg}}$ \\
\hline
\end{tabular}

Table 2. Statistical comparison of photosynthetic performance of algal-biophotovoltaic device with suspended and immobilized of Chlorella UMACC 313 under conventional white LED light and PLA on days $0,4,8$, and 12. Data as means \pm S.D. $(n=3)$. Different letters indicate significant difference between different values (ANOVA, Tukey's HSD test, $\mathrm{p}<0.05)$.

with $\mathrm{CO}_{2}$ for fixation by rubisco and therefore reduce the $\mathrm{CO}_{2}$-fixation rate. To overcome this, alga cells pump sufficient bicarbonate into cells to ensure the $\mathrm{CO}_{2}$ concentration levels are higher than those achievable by equilibrium with air ${ }^{32}$.

Impact analysis of our algal biophotovoltaic devices was conducted using the OpenLCA software (Version 1.10.3). In our model, we set five algal BPV devices as basis and identified to our best ability, the resources required in producing our devices so that relevant calculations can be made by the software. We note that the data generated are estimated values, as they may differ depending on the databases used for the input section in our model graph. The impact assessment method that we used was CML2001-Apr. 2013. We found that the estimated amount of carbon dioxide emitted to the atmosphere as a result of developing our algal BPV device system (in replicates of five) is approximately $0.308 \mathrm{~kg} \mathrm{CO}_{2}$. The main contributing factors are the polymethyl methacrylate (PMMA) used in manufacturing the cylindrical chamber of the algal BPV device and the copper wires used to complete the circuit. This system also leads to an abiotic depletion (ADP elements) of $2.15 \times 10^{-5} \mathrm{~kg} \mathrm{Sb}$ eq.

Photosynthetic performance of Chlorella UMACC 313 in the algal BPV devices. Table 2 gives details of the photosynthetic performance of Chlorella in the BPVs, under control and treatment conditions, on days $0,4,8$, and 12 . Fluorescence characteristics of the BPV devices exposed to different light source were different, indicating a strong effect of the light spectrum on photosynthetic performance.

The maximum quantum yield $\left(\mathrm{F}_{\mathrm{v}} / \mathrm{F}_{\mathrm{m}}\right)$ which is used to indicate physiological health in the algae is inversely related to stress levels of the cells. The threshold for stress in Chlorella is $\mathrm{Fv} / \mathrm{Fm}=0.5^{10}$. Low $\mathrm{F}_{\mathrm{v}} / \mathrm{F}_{\mathrm{m}}$ values were observed on day 0 for suspended and immobilized Chlorella culture under both conditions. This is due to adjustment of the inoculum in a new environment. Fv/Fm values of the suspended algae was lower $(\mathrm{p}<0.05)$ under treatment conditions compared to the control, and this trend continued throughout the experiment. Increased Fv/Fm values may be due to higher photosynthetic activity under optimised irradiance. As the cultures grew, the physiological health of the Chlorella cells improved, and higher $\mathrm{F}_{\mathrm{v}} / \mathrm{F}_{\mathrm{m}}$ values $(>0.45, \mathrm{p}<0.05)$ were observed starting on day 4 for all conditions. Day 4 to day 8 is considered to be the exponential growth phase.

Photosynthetic efficiency (PE) alpha $(\alpha)$ is an important indicator to define the fraction of available incident light within the solar spectrum that is stored as chemical energy in biomass. Increasing PE is a promising approach to enhance microalgae productivity. PE is derived as the fraction of light energy converted into chemical energy during photosynthesis process ${ }^{33}$. a values increased from day 0 to day 8 , as the algae adjusted and grew. There was a small reduction in $\alpha$ on day 12 , especially in the immobilized cells. This may be due to reduced light availability per cell due to higher cell density. The algae in the BPVs exposed to treatment condition had higher $\alpha(\mathrm{p}<0.05)$ compared to the control. On day $8, \alpha=0.794$ and 0.844 for suspended and immobilized algae, respectively. Cells exposed to the simulated spectrum (treatment) showed higher a values, presumably because the spectrum was closer to the absorption spectrum of the Chlorella cells, allowing the pigments to more efficiently use the energy for photosynthesis.

The maximum relative electron transport rate $\left(\mathrm{rETR}_{\max }\right)$ was higher in the algae exposed to treatment condition, with the highest value on day $4\left(254 \mu \mathrm{mol}\right.$ electrons $\left.\mathrm{m}^{-2} \mathrm{~s}^{-1}\right)$ for suspended algae and day $8(190.5 \mu \mathrm{mol}$ electrons $\mathrm{m}^{-2} \mathrm{~s}^{-1}$ ) for immobilized algae. The higher $\mathrm{rETR}_{\max }$ occurred during the exponential growth phase, when the cells were actively growing, and biomass was highest (Table 1). The relationship between $\mathrm{rETR}_{\max }$ and power output will be discussed in the next section. 


\begin{tabular}{|c|c|c|c|c|c|c|}
\hline \multirow[b]{2}{*}{ Day } & \multirow[b]{2}{*}{ Light source } & \multirow[b]{2}{*}{ Condition } & \multicolumn{2}{|c|}{$\begin{array}{l}\text { Maximum current density } \\
\left(\mathrm{mA} \mathrm{m}^{-2}\right)\end{array}$} & \multicolumn{2}{|c|}{$\begin{array}{l}\text { Maximum power density ( } \mathrm{mW} \\
\mathrm{m}^{-2} \text { ) }\end{array}$} \\
\hline & & & Light & Dark & \begin{tabular}{|l|} 
Light \\
\end{tabular} & Dark \\
\hline \multirow{2}{*}{0} & \multirow{8}{*}{$\begin{array}{l}\text { Conventional white LED light } \\
90 \mu \mathrm{mol} \text { photons } \mathrm{m}^{-2} \mathrm{~s}^{-1}\end{array}$} & Suspended & $1.667 \pm 0.024^{\mathrm{f}}$ & $1.297 \pm 0.034^{\mathrm{h}}$ & $0.069 \pm 0.010^{j}$ & $0.051 \pm 0.004^{\mathrm{e}}$ \\
\hline & & Immobilized & $2.769 \pm 0.072^{\mathrm{e}}$ & $2.363 \pm 0.028^{\mathrm{g}}$ & $0.173 \pm 0.008^{\mathrm{fg}}$ & $0.127 \pm 0.011^{\mathrm{d}}$ \\
\hline \multirow{2}{*}{4} & & Suspended & $2.87 \pm 0.21^{\mathrm{e}}$ & $2.495 \pm 0.047^{\mathrm{g}}$ & $0.095 \pm 0.005^{\mathrm{ij}}$ & $0.079 \pm 0.001^{\mathrm{de}}$ \\
\hline & & Immobilized & $3.889 \pm 0.076^{\mathrm{d}}$ & $2.714 \pm 0.048^{g}$ & $0.129 \pm 0.004^{\mathrm{hi}}$ & $0.0824 \pm 0.011^{\mathrm{de}}$ \\
\hline \multirow{2}{*}{8} & & Suspended & $1.91 \pm 0.12^{\mathrm{f}}$ & $1.640 \pm 0.072^{\mathrm{h}}$ & $0.156 \pm 0.008^{\text {gh }}$ & $0.102 \pm 0.002^{\mathrm{de}}$ \\
\hline & & Immobilized & $3.95 \pm 0.10^{\mathrm{d}}$ & $2.724 \pm 0.077^{\mathrm{fg}}$ & $0.202 \pm 0.012^{\mathrm{f}}$ & $0.133 \pm 0.002^{\mathrm{d}}$ \\
\hline \multirow{2}{*}{12} & & Suspended & $1.93 \pm 0.11^{\mathrm{f}}$ & $1.697 \pm 0.091^{\mathrm{h}}$ & $0.113 \pm 0.006^{\mathrm{hij}}$ & $0.084 \pm 0.004^{\mathrm{de}}$ \\
\hline & & Immobilized & $3.10 \pm 0.38^{\mathrm{e}}$ & $2.43 \pm 0.27^{\mathrm{g}}$ & $0.149 \pm 0.014^{\mathrm{gh}}$ & $0.117 \pm 0.007^{\mathrm{de}}$ \\
\hline \multirow{2}{*}{0} & \multirow{8}{*}{$\begin{array}{l}\text { PLA } \\
90 \mu \mathrm{mol} \text { photons } \mathrm{m}^{-2} \mathrm{~s}^{-1}\end{array}$} & Suspended & $3.85 \pm 0.26^{\mathrm{d}}$ & $2.493 \pm 0.045^{g}$ & $0.378 \pm 0.013^{\mathrm{e}}$ & $0.128 \pm 0.008^{\mathrm{d}}$ \\
\hline & & Immobilized & $4.69 \pm 0.10^{\mathrm{bc}}$ & $4.40 \pm 0.32^{\mathrm{bc}}$ & $0.468 \pm 0.004^{\mathrm{bc}}$ & $0.384 \pm 0.055^{\mathrm{ab}}$ \\
\hline \multirow{2}{*}{4} & & Suspended & $4.19 \pm 0.21^{\mathrm{cd}}$ & $3.32 \pm 0.21^{\mathrm{ef}}$ & $0.418 \pm 0.027^{\mathrm{de}}$ & $0.334 \pm 0.042^{\mathrm{bc}}$ \\
\hline & & Immobilized & $5.30 \pm 0.14^{\mathrm{b}}$ & $4.977 \pm 0.015^{b}$ & $0.557 \pm 0.029^{\mathrm{a}}$ & $0.408 \pm 0.009^{\mathrm{a}}$ \\
\hline \multirow{2}{*}{8} & & Suspended & $5.37 \pm 0.17^{\mathrm{b}}$ & $3.61 \pm 0.23^{\mathrm{de}}$ & $0.502 \pm 0.026^{\mathrm{b}}$ & $0.329 \pm 0.026^{\mathrm{bc}}$ \\
\hline & & Immobilized & $6.78 \pm 0.30^{\mathrm{a}}$ & $5.70 \pm 0.37^{\mathrm{a}}$ & $0.581 \pm 0.009^{\mathrm{a}}$ & $0.451 \pm 0.034^{\mathrm{a}}$ \\
\hline \multirow{2}{*}{12} & & Suspended & $5.13 \pm 0.46^{\mathrm{b}}$ & $4.20 \pm 0.18^{\mathrm{cd}}$ & $0.422 \pm 0.009^{\mathrm{de}}$ & $0.310 \pm 0.028^{c}$ \\
\hline & & Immobilized & $6.17 \pm 0.38^{\mathrm{a}}$ & $4.47 \pm 0.41^{\mathrm{bc}}$ & $0.440 \pm 0.009^{\text {cd }}$ & $0.332 \pm 0.017^{\mathrm{bc}}$ \\
\hline
\end{tabular}

Table 3. Statistical comparison of power output of algal-biophotovoltaic device with suspended and immobilized of Chlorella UMACC 313 in dark and light conditions under conventional white LED light and PLA on days $0,4,8$, and 12 . Data as means \pm S.D. $(n=3)$. Different letters indicate significant difference between different values (ANOVA, Tukey s HSD test, $\mathrm{p}<0.05$ ).

The photoadaptive index $\left(\mathrm{E}_{\mathrm{k}}\right)$ was significantly higher $(\mathrm{p}<0.05)$ under treatment condition and ranged from $91.8 \mu \mathrm{mol}$ photons $\mathrm{m}^{-2} \mathrm{~s}^{-1}$ (day 0 , immobilized algae) to $427 \mu \mathrm{mol}$ photons $\mathrm{m}^{-2} \mathrm{~s}^{-1}$ (day 4 , suspended algae). In general, the adaptive index was higher in suspended algae compared to immobilized algae. In the BPV with suspended algae, the cells were dispersed in the medium, compared to the immobilized culture where the cells were found only in the approximately $2 \mathrm{~mm}$ thick alginate film. Thus it appears that the highly dispersed condition allowed for a higher light saturation level ${ }^{11}$.

Autotrophic microalgae use visible light (400-700 nm) as the main source of radiant energy to generate adenosine triphosphate (ATP) and nicotinamide adenine dinucleotide phosphate (NADPH) via the photosynthesis process $^{18}$. The energy content of irradiance at wavelengths above $750 \mathrm{~nm}$ is too low to mediate a chemical change in microalgal cells, hence radiant energy absorbed in this range is dissipated as thermal energy ${ }^{34}$. Irradiance of $380 \mathrm{~nm}$ and below has ionizing effects. So, wavelengths between 380 and $750 \mathrm{~nm}$ have energy able to produce chemical change in the absorbing molecules, as happens throughout the photosynthetic pathway ${ }^{18}$. For Chlorella UMACC 313 used in this study, major wavelengths utilised by the pigments are within the range 420-440 nm and $650-670 \mathrm{~nm}$, and accessory wavelengths are located below, between or above these ranges ${ }^{20}$. Light energy emitted by the PLA provides ideal energy levels required by Chlorella UMACC 313 to initiate photosynthesis, and the highest $\alpha$ and $\mathrm{rETR}_{\max }$ were stimulated by the PLA in this experiment.

Bioelectricity generation by Chlorella UMACC313 in the algal BPV devices. Table 3 shows the details of the power output from the BPVs containing suspended and immobilized algae, under control and treatment conditions, on days $0,4,8$, and 12 . Power density was measured under light and dark conditions. Figures 2 and 3 show maximum current density and maximum power density of algal-biophotovoltaic device with suspended and immobilized of Chlorella UMACC 313 in dark and light conditions under conventional white LED light and PLA on days $0,4,8$, and 12 . In a previous study, we reported that our alginate immobilized algalBPV produced a peak power density $\left(0.289 \mathrm{~mW} \mathrm{~m}^{-2}\right)$ on day $8^{11}$. In the present study, the highest power density was recorded from immobilized algal-BPV on day 8 (exponential phase culture) for both light treatments. When the immobilized algal-BPV was exposed to control condition, the highest power densities were $0.202 \mathrm{~mW} \mathrm{~m}^{-2}$ and $0.133 \mathrm{~mW} \mathrm{~m}^{-2}$ in light and dark conditions, respectively. When the immobilized algal-BPV was exposed to treatment conditions, there was an increase of power density from 0.202 to $0.581 \mathrm{~mW} \mathrm{~m}^{-2}(65.2 \%)$ in the light, and from 0.133 to $0.451 \mathrm{~mW} \mathrm{~m}^{-2}(70.5 \%)$ in the dark. The reason for the high power output is the same as for higher photosynthetic performance; that is, the spectrum provided by the PLA was compatible with the absorption spectrum of the algal pigments ${ }^{11}$.

In our present study, power output based on algal biomass (using chl- $a$ content, Table 1 ) was estimated to be $5.09 \mathrm{~mW} \mathrm{~m} / \mathrm{mg}$ chl- $a$ (light condition) and $3.35 \mathrm{~mW} \mathrm{~m}^{-2} / \mathrm{mg}^{-2} \mathrm{l}-a$ (dark condition) when the immobilized algal-BPV was exposed to control condition. When the immobilized algal-BPV was exposed to the treatment conditions, the power output based on algal biomass (using chl- $a$ content) was higher, at $11.80 \mathrm{~mW} \mathrm{~m}^{-2} / \mathrm{mg}^{-}$ chl- $a$ and $9.16 \mathrm{~mW} \mathrm{~m} \mathrm{~m}^{-2} / \mathrm{mg}$ chl- $a$, respectively. Figures 4 and 5 show the polarization curves of suspended and immobilized algae BPV under control conditions, while Figs. 6 and 7 show polarization curves under treatment conditions. 


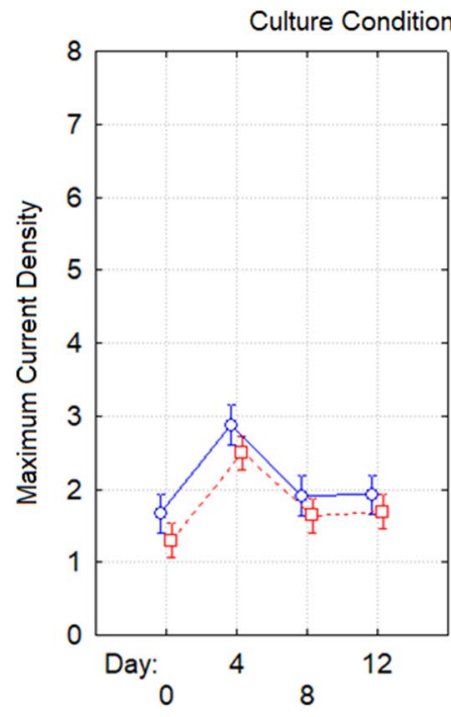

Light Source: White LED Light

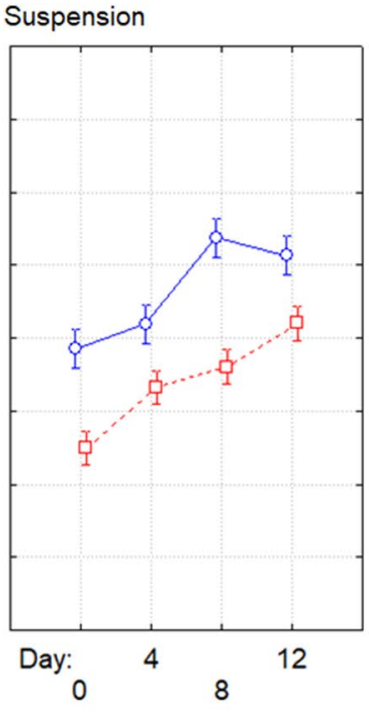

Light Source: PLA

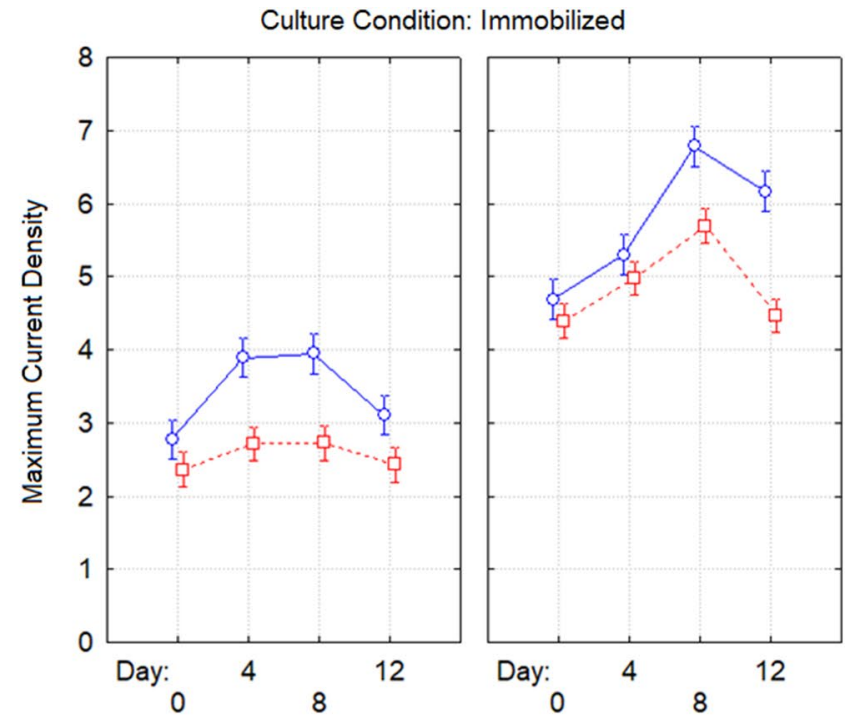

Light Source: White LED Light

Light Source: PLA

Figure 2. Maximum current density of algal-biophotovoltaic device with suspended and immobilized of Chlorella UMACC 313 in dark and light conditions under conventional white LED white light and PLA on days $0,4,8$, and 12. Data as means \pm S.D. $(\mathrm{n}=3)$.

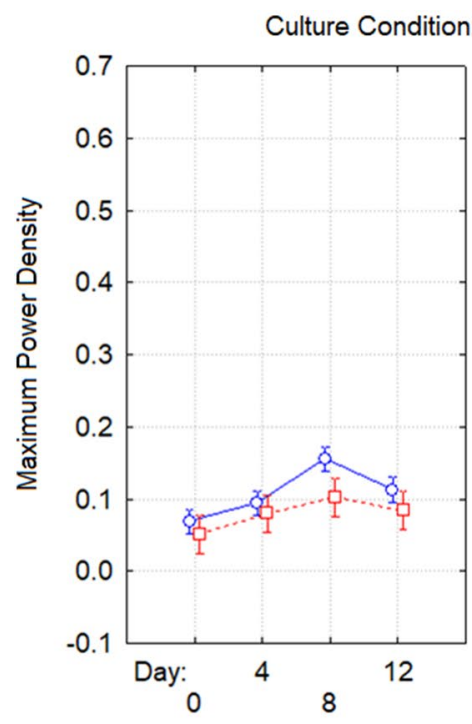

Light Source: White LED Light

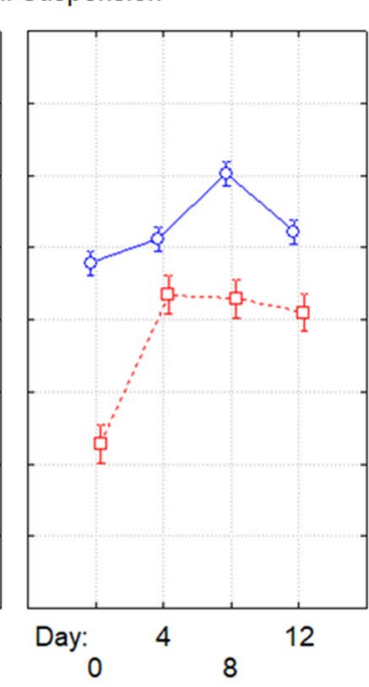

Light Source: PLA

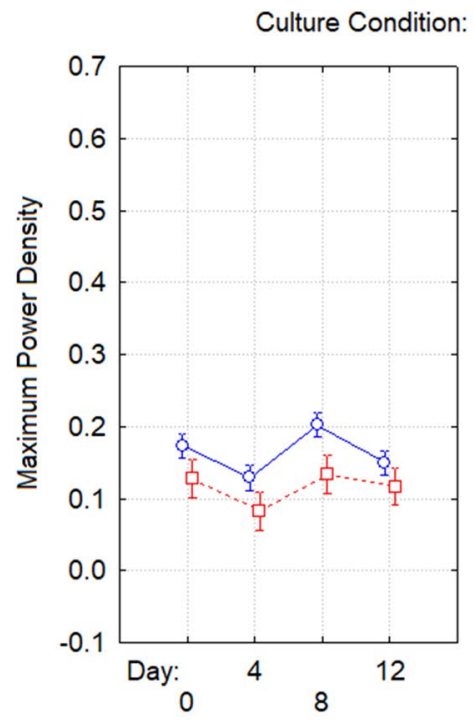

Light Source: White LED Light

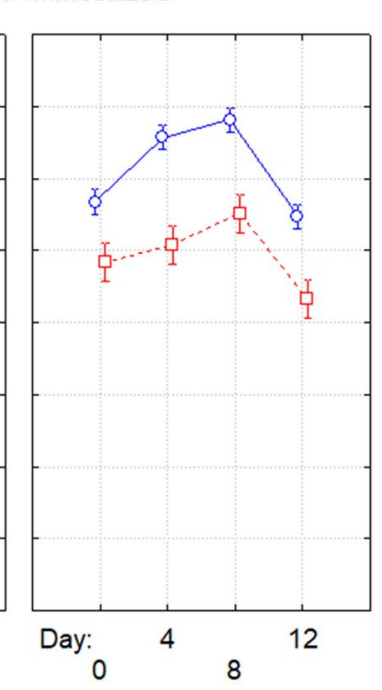

Light Source: PLA 하- Maximum Power Density (Light)
도. Maximum Power Density (Dark)

Figure 3. Maximum power density of algal-biophotovoltaic device with suspended and immobilized of Chlorella UMACC 313 in dark and light conditions under conventional white LED white light and PLA on days $0,4,8$, and 12. Data as means \pm S.D. $(\mathrm{n}=3)$.

The data in the present study indicates that the higher power output generated from the algal-BPV devices exposed to treatment conditions compared to control conditions may be attributed to optimum light quality received by Chlorella cells. Improved biomass production and photosynthetic performance led to improved bioelectric generation, with the use of optimized light spectrum. Microalgal PSII is enhanced by red light wavelengths while PSI is enhanced by blue light wavelengths; blue light enhances chlorophyll and carotenoid synthesis, as well 


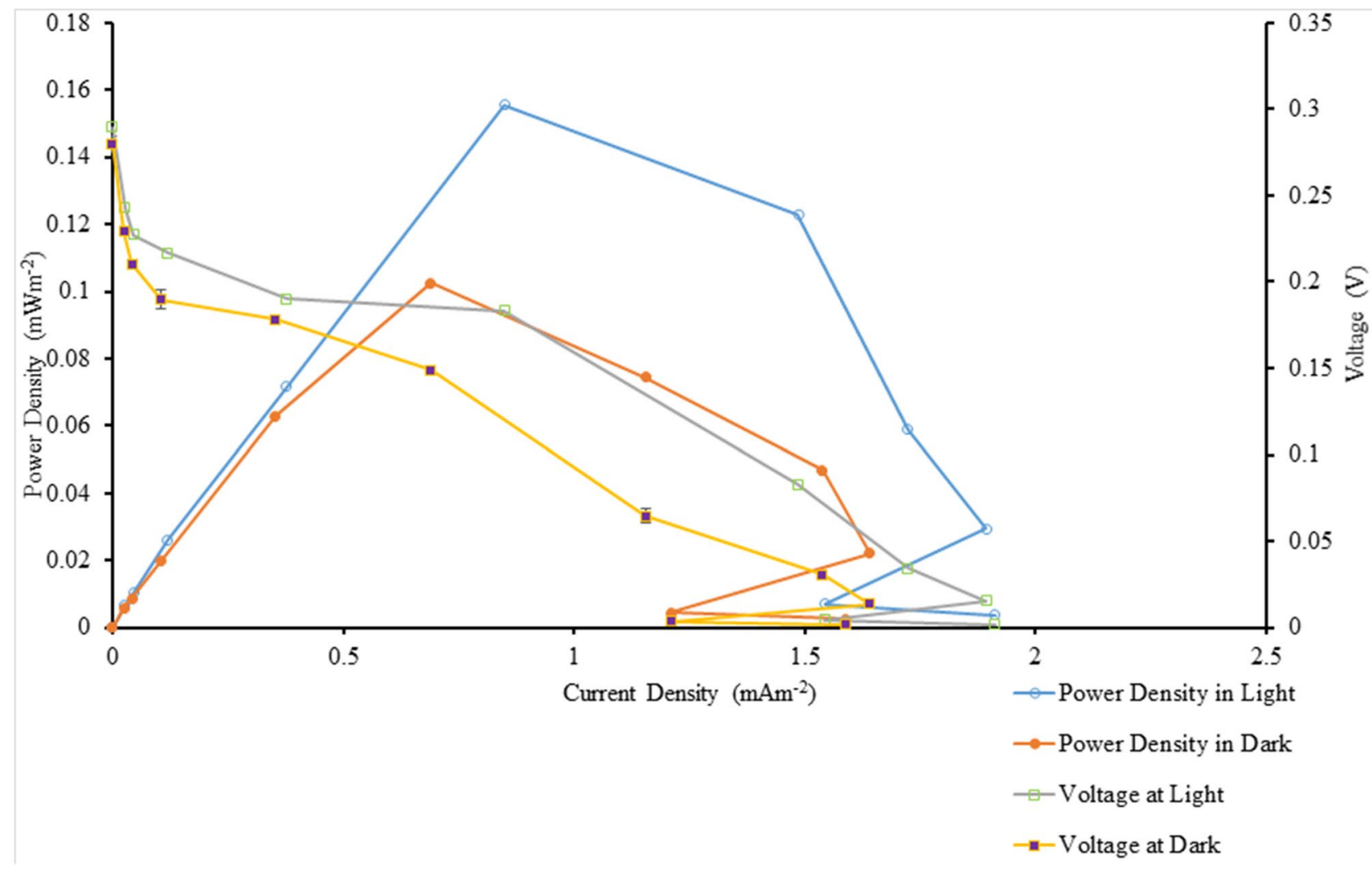

Figure 4. The polarization curve from suspended Chlorella UMACC 313 biophotovoltaic devices under conventional LED white light $\left(90 \mu \mathrm{mol}\right.$ photons $\left.\mathrm{m}^{-2} \mathrm{~s}^{-1}\right)$ on day 8. Data as means \pm S.D. $(\mathrm{n}=3)$.

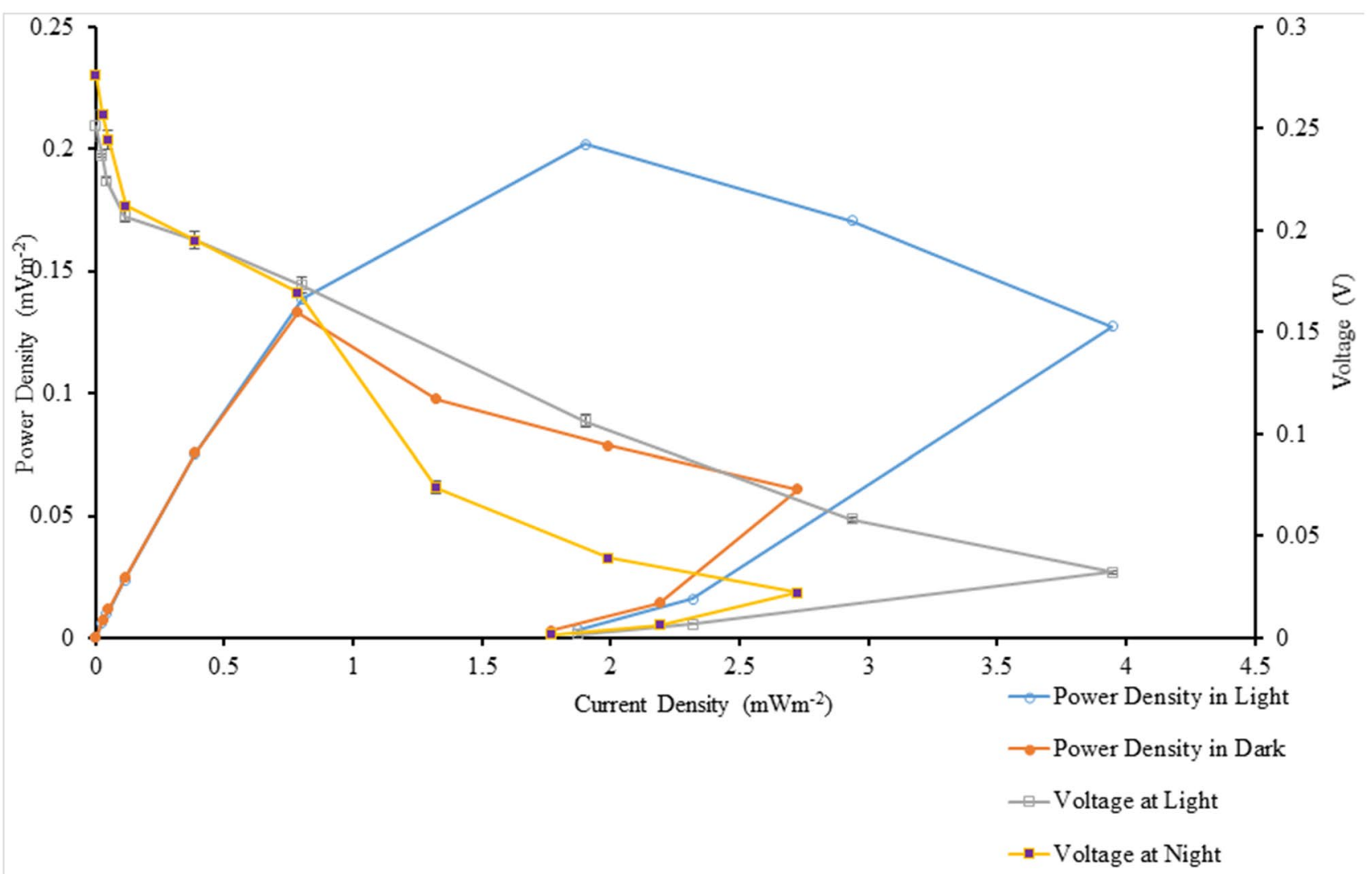

Figure 5. The polarization curve from immobilized Chlorella UMACC 313 biophotovoltaic devices under conventional LED white light $\left(90 \mu \mathrm{mol}\right.$ photons $\left.\mathrm{m}^{-2} \mathrm{~s}^{-1}\right)$ on day 8 . Data as means \pm S.D. $(\mathrm{n}=3)$. 


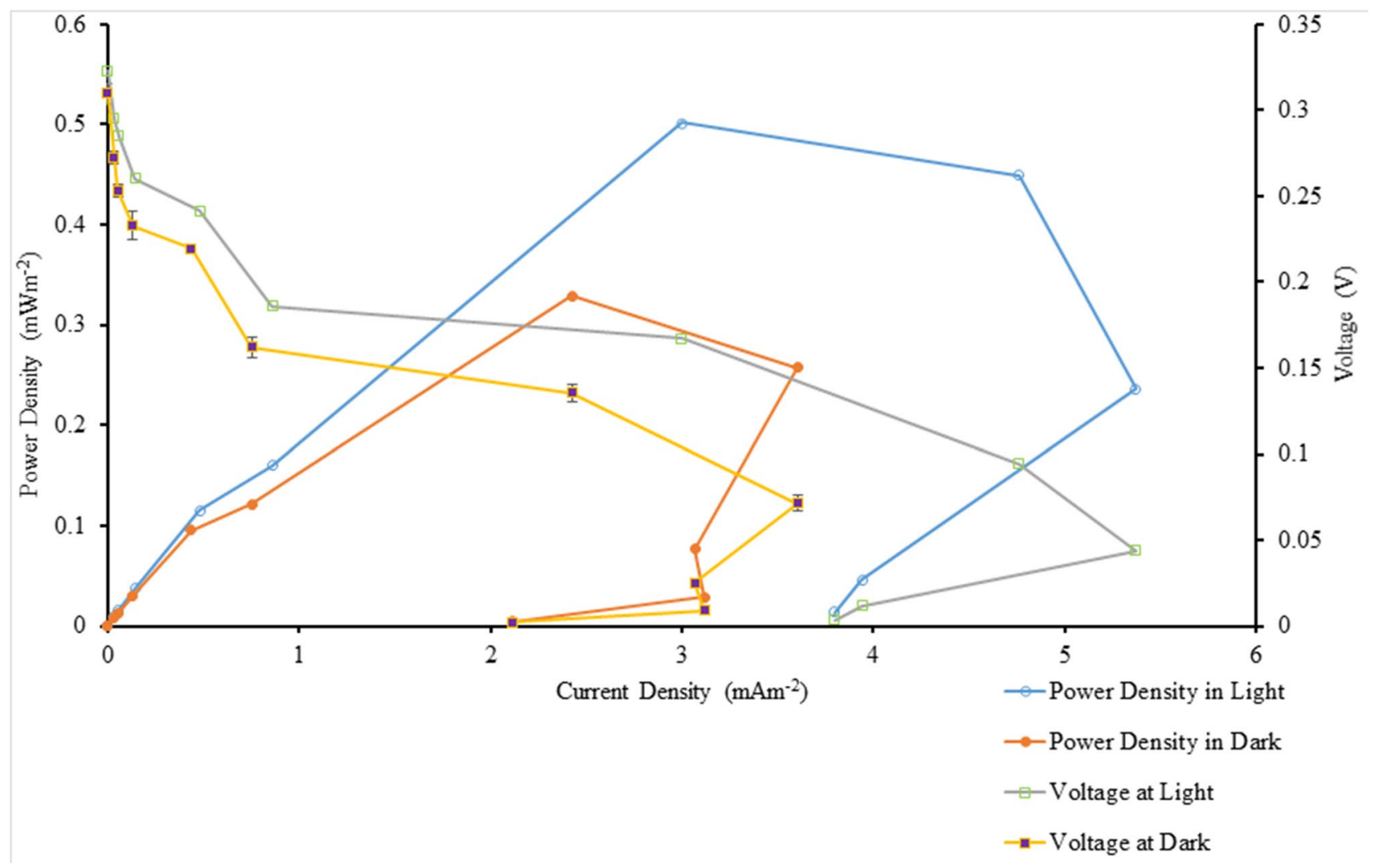

Figure 6. The polarization curve from suspended Chlorella UMACC 313 biophotovoltaic devices under PLA $\left(90 \mu \mathrm{mol}\right.$ photons $\left.\mathrm{m}^{-2} \mathrm{~s}^{-1}\right)$ on day 8 . Data as means \pm S.D. $(\mathrm{n}=3)$.

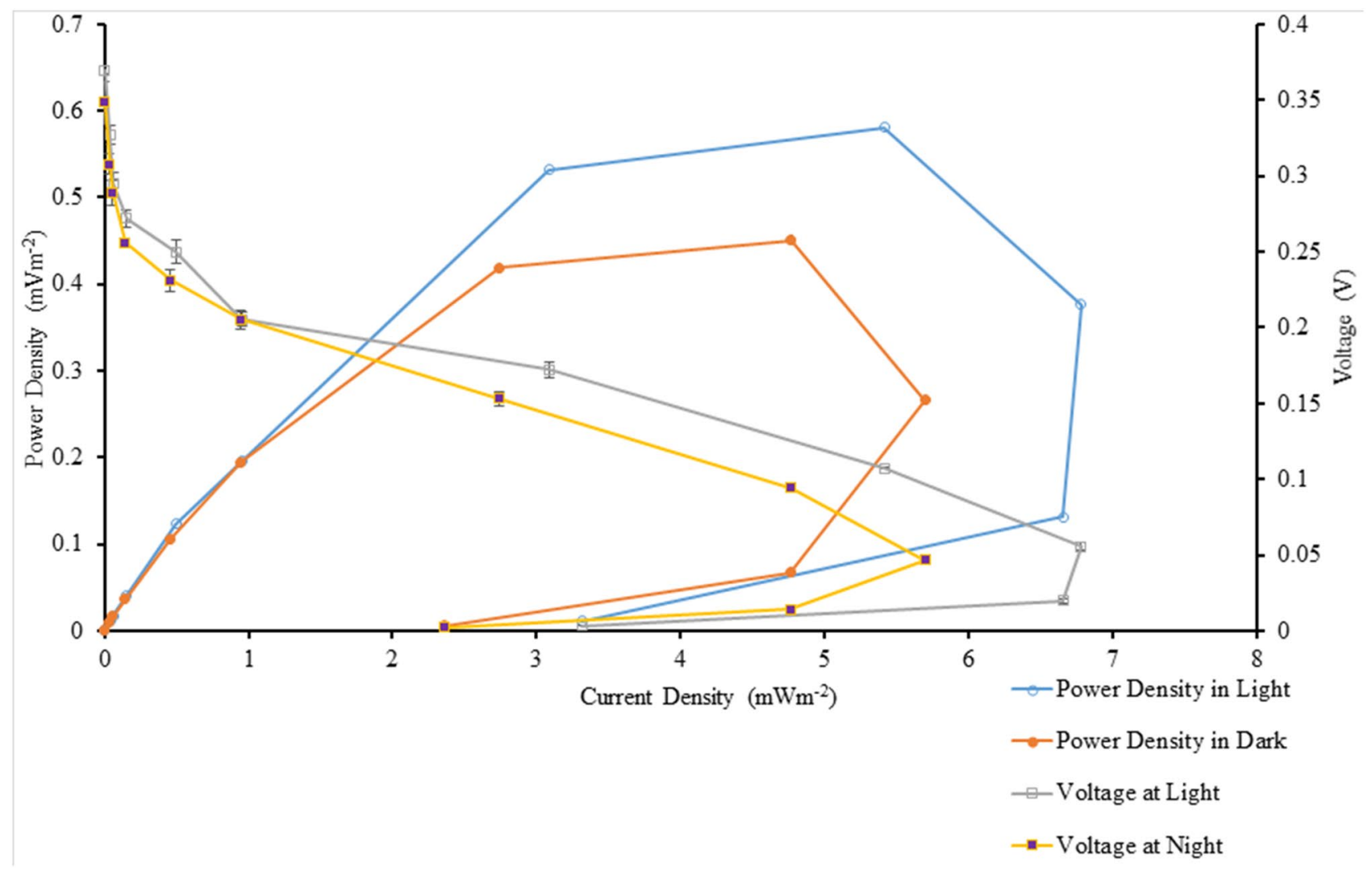

Figure 7. The polarization curve from immobilized Chlorella UMACC 313 biophotovoltaic devices under PLA $\left(90 \mu \mathrm{mol}\right.$ photons $\left.\mathrm{m}^{-2} \mathrm{~s}^{-1}\right)$ on day 8 . Data as means \pm S.D. $(\mathrm{n}=3)$. 


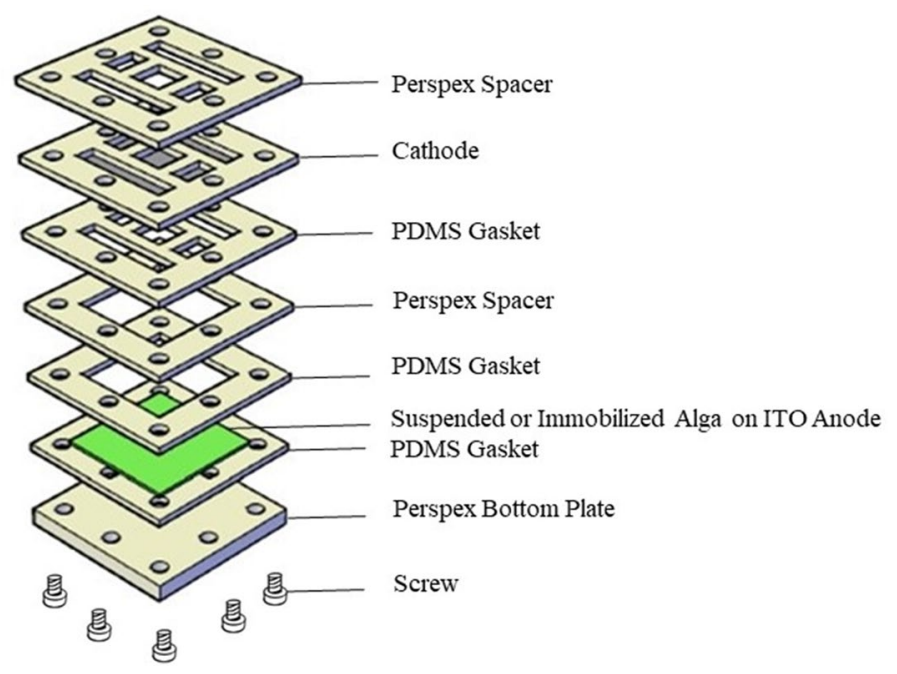

Figure 8. Exploded view of the ITO based BPV device.

as nitrogen metabolism ${ }^{35}$. Higher light intensity $\left(90 \mu \mathrm{mol}\right.$ photons $\left.\mathrm{m}^{-2} \mathrm{~s}^{-1}\right)$ in the current study also contributed to the higher power output. Li et al. ${ }^{36}$ reported the effects of white LED light of different light intensities on Chlorella pyrenoidosa; the highest growth rate, $97.8 \mathrm{mg} \mathrm{L}^{-1}$ occurred at $90 \mu \mathrm{mol}$ photons $\mathrm{m}^{2} \mathrm{~s}^{-1}$.

While the BBM provides complete nutrients for microalgal growth, ions in the medium also influence the bioelectricity generation from the algal BPV device. Electrical conductivity in liquid depends on the concentration of ions, such as hydrogen $\left(\mathrm{H}^{+}\right)$, hydroxide $\left(\mathrm{OH}^{-}\right)$, phosphate and nitrate, which are also nutrients present in $\mathrm{BBM}$ thus contribute to the conductivity ${ }^{37}$. In our previous study, we reported that power density of $0.066 \mathrm{~mW}$ $\mathrm{m}^{-2}$ was detected in our BPV device (only BBM medium and without microalgae). However, the power generated by the algae with BBM $\left(0.345 \pm 0.056 \mathrm{~mW} \mathrm{~m}^{-2}\right)$ was significantly higher (ANOVA, $\mathrm{P}<0.05$ ), indicating that the Chlorella UMACC 313 cells were the main contributing factor in power generation from the algal BPV devices ${ }^{38}$.

\section{Conclusion}

In photoautotrophic algal growth, radiant energy drives the metabolic activities of the cells, through production of chemical energy and reducing power via photosynthesis. In addition, a new role of the photosynthetic algal cells is the production of bioelectricity. Wavelength and intensity characteristics of the light source are critical factors for the growth of algae. This study has shown that when artificial light is provided, as through the PLA, a peak power output of $0.581 \mathrm{~mW} \mathrm{~m}^{-2}$ was generated, which is an increase of $188 \%$ compared to operation under a conventional white LED light source. For this study, we manipulated the light quality to provide spectrally optimised light for the pigments (specifically chl-a) of Chlorella UMACC 313 and demonstrated improved biomass production, photosynthetic performance and bioelectricity generation. Realization of a pilot scale energy harvesting system can be achieved when optimum artificial light source combined with algal BPV devices are integrated into a power management system for low power applications (eg. environment sensor for indoor agriculture system).

\section{Methods}

Algal culture. A local tropical algal strain from the University of Malaya Algae Culture Collection (UMACC) Chlorella UMACC 313, a chlorophyte, isolated from palm oil mill effluent, was used for this study. Stock cultures were prepared by inoculating exponential phase culture (20\% inoculum) standardized at an optical density (OD) of 0.2 at $620 \mathrm{~nm}\left(\mathrm{OD}_{620 \mathrm{~nm}}\right)$ into Bold's Basal Medium $(\mathrm{BBM})^{39}$ in $1 \mathrm{~L}$ conical flasks (total volume of culture: $500 \mathrm{~mL})$. The flasks were placed in an incubator shaker $(120 \mathrm{rpm})$ at $25^{\circ} \mathrm{C}$, with irradiance of $40 \mu \mathrm{mol}$ photons $\mathrm{m}^{-2} \mathrm{~s}^{-1}$ on a 12:12 light:dark cycle.

Preparation of algal BPV devices. The algal BPV device was a closed, single-chamber BPV, consisting of a $50 \times 50 \mathrm{~mm}$ platinum-coated glass cathode, which was placed in parallel with an ITO coated glass (KINTEC, Hong Kong) anode. The body of the open-air, single-chamber BPV was constructed of clear Perspex (Fig. 8).

Preparation of immobilized algae. Immobilized algae were grown on the surface of the anode in a clear Perspex chamber sealed with polydimethylsiloxane (PDMS) and then filled with fresh BBM. The algal cells were immobilized in $2 \%$ sodium alginate. Sodium alginate powder ( 2 g; Natural Colloids Industries Pte. Ltd.) was added into $95 \mathrm{~mL}$ of sterile distilled water and stirred continuously using a magnetic stirrer overnight to prepare the $2 \%$ sodium alginate solution. Chlorella sp. cells were suspended in BBM to form a concentrated algal suspension $\left(\mathrm{OD}_{620 \mathrm{~nm}}=2.0\right)$ of which $5 \mathrm{~mL}$ were added to the $95 \mathrm{~mL}$ sodium alginate solution to form the algal alginate suspension. ITO-coated $3.5 \mathrm{~cm} \times 3.5 \mathrm{~cm}$ glass slides were placed in a mould made by sterile aluminium foil. A pipette was used to spread $3 \mathrm{~mL}$ of the algal alginate suspension on the ITO-coated glass slides and the 
algal alginate suspension allowed to settle for $15 \mathrm{~min}$. Sterile $\mathrm{CaCl}_{2}(0.1 \mathrm{M})$ was sprayed onto the surface of the suspension until it was fully covered. Samples were left for one hour to complete the gelation process to form a $2 \mathrm{~mm}$ thick algal gel film on the ITO. The film was measured with Elcometer 3230 Wet Film Wheels. The ITO anode with the algal gel film was rinsed with sterile distilled water to remove the $\mathrm{CaCl}_{2}$ solution after the culture immobilization process was completed ${ }^{6}$.

Preparation of suspended algae. The algal suspensions were prepared using exponential phase cultures in BBM, where $5 \mathrm{~mL}$ of concentrated Chlorella sp. $\left(\mathrm{OD}_{620 \mathrm{~nm}}=2.0\right)$ was added to the $95 \mathrm{~mL}$ BBM medium. Suspension cell cultures, for comparison with the immobilized cultures, were grown in the same way as above, and placed on top of the ITO anode in the BPVs.

Chl- $\boldsymbol{a}$ and carotenoids concentration. Biomass was estimated based on chl- $a$ content. Carotenoid concentration was used as a stress indicator ${ }^{40}$. The chl- $a$ and carotenoid concentrations were determined using the spectrophotometric method ${ }^{41}$. The suspended culture was pipetted out from the BPV and collected on a glassfibre filter paper (Whatman GF/C, $0.45 \mu \mathrm{m}$ ). For the immobilized algae, the alginate layer was removed from the ITO anode. Both types of samples were mashed in $10 \mathrm{~mL}$ of analytical grade $100 \%$ acetone using a hand homogenizer. The samples were then kept at $4{ }^{\circ} \mathrm{C}$ for $24 \mathrm{~h}$ before centrifugation at $3000 \mathrm{rpm}$ for $10 \mathrm{~min}$ at $4{ }^{\circ} \mathrm{C}$. Absorption of the supernatant was measured at $630 \mathrm{~nm}\left(\mathrm{OD}_{630}\right), 645 \mathrm{~nm}\left(\mathrm{OD}_{645}\right), 665 \mathrm{~nm}\left(\mathrm{OD}_{665}\right)$, and $452 \mathrm{~nm}$ $\left(\mathrm{OD}_{452}\right)$, using a Shimadzu UV 1800 spectrophotometer. All measurements were conducted in triplicates. All statistical analyses were performed using the Statistica 8 program.

The chl- $a$ concentration was calculated using the following formula:

$$
\mathrm{Chl}-\mathrm{a}\left(\mathrm{mg} \mathrm{m}^{-3}\right)=(\mathrm{Ca} \times \mathrm{Va}) / \mathrm{Vc}
$$

where

$$
\mathrm{Ca}=11.6 \times \mathrm{OD}_{665 \mathrm{~nm}}-1.31 \times \mathrm{OD}_{645 \mathrm{~nm}}-0.14 \times \mathrm{OD}_{630 \mathrm{~nm}} .
$$

Va is the volume of acetone $(\mathrm{mL})$ used for extraction, Vcis the volume of culture $(\mathrm{L})$.

$$
\text { Chl-a }(\mathrm{mg} / \mathrm{L})=\mathrm{Chl}-\mathrm{a}\left(\mathrm{mg} \mathrm{m}^{-3}\right) / 1000 \text {. }
$$

The carotenoid concentration was calculated using the following formula:

$$
\text { Carotenoids }(\mathrm{mg} / \mathrm{L})=\left(\mathrm{OD}_{452} \times 3.86 \times \mathrm{Va}\right) / \mathrm{Vc}
$$

where Va is the volume of acetone $(\mathrm{mL})$ used for extraction, Vc is the volume of culture $(\mathrm{mL})$.

Cell count. Cell density (cells $\mathrm{mL}^{-1}$ ) was also used for biomass estimation and was determined using an improved Double-Neubauer Haemocytometer ${ }^{42}$. Appropriate dilution and homogenization of the algal cultures were performed to limit the cell number to below 100 per counting chamber.

Specific growth rate. The specific growth rate $(\mu)$ was calculated based on chl- $a$ content $\left(\mathrm{mg} \mathrm{L}^{-1}\right) \mathrm{using}$ the following formula:

$$
\text { SGR, } \mu\left(\text { day }^{-1}\right)=\left(\operatorname{Ln~} N_{2}-\operatorname{Ln} N_{1}\right) / t_{2}-t_{1}
$$

where $\mathrm{N}_{2}$ is the chl- $a\left(\mathrm{mg} \mathrm{L}^{-1}\right)$ at $\mathrm{t}_{2}$ time, $\mathrm{N}_{1}$ is the chl- $a\left(\mathrm{mg} \mathrm{L}^{-1}\right)$ at $\mathrm{t}_{1}$ time, $\mathrm{t}_{2}$ and $\mathrm{t}_{1}$ are the times within the exponential phase ${ }^{42}$.

Carbon and $\mathrm{CO}_{2}$ fixation. The carbon fixation and $\mathrm{CO}_{2}$ fixation rates were estimated as follows ${ }^{43}$ :

$$
\text { Carbon fixation, } \mathrm{mg} \text { carbon } \mathrm{L}^{-1}=50 \% \text { of the cell's biomass }
$$

where biomass $(\mathrm{mg})=\mathrm{Chl}-\mathrm{a}$ content $\left(\mathrm{mg} \mathrm{L}^{-1}\right) \times 67$, assuming that Chl-a makes up $1.5 \%$ of the cell 478 biomass.

$$
\mathrm{CO}_{2} \text { fixation rates, } \mathrm{mg} \mathrm{L}^{-1} \text { day }^{-1}=0.5 P \times(44 / 12)
$$

where $\mathrm{P}$ is the biomass productivity $=\left(\right.$ biomass at $\mathrm{t}_{2}$ - biomass at $\left.\mathrm{t}_{1}\right) /\left(\mathrm{t}_{2}-\mathrm{t}_{1}\right), 44$ is the molecular weight of carbon dioxide $\left(\mathrm{gmol}^{-1}\right), 12$ is the atomic weight of carbon $\left(\mathrm{gmol}^{-1}\right)^{43}$.

Pulse amplitude modulation fluorometer measurement. Fluorescence analysis was employed to measure the photosynthetic performance of algal cultures in the BPV devices. Photosynthetic parameters in this study were measured using a pulse amplitude modulation (PAM) fluorometer (Diving PAM, Walz, Germany) ${ }^{44}$. A rapid light curve (RLC) was obtained under software control (Wincontrol, Walz) using eight consecutive ten-second intervals of actinic light with increasing intensity (light levels: 0, 47, 139, 272, 414, 602, 817, 1179 and $1566 \mu \mathrm{mol}$ photons $\mathrm{m}^{-2} \mathrm{~s}^{-1}$ ). The cultures were dark-adapted for $15 \mathrm{~min}$ before exposure to different light level. The maximum photosynthetic efficiency was determined from the initial slope ( $\alpha$ ) of the RLC. The relative electron transport rate (rETR) was calculated by multiplying the irradiance by the quantum yield (ratio of the number of photons emitted to the number of photons absorbed) measured with the Diving-PAM at the end of each light interval. The photoadaptive index $\left(\mathrm{E}_{\mathrm{k}}\right)$ is the value of the irradiance where the rETR is a maximum ${ }^{45}$. 
Maximum quantum efficiency $\left(\mathrm{F}_{\mathrm{v}} / \mathrm{F}_{\mathrm{m}}\right)$, was used to indicate if the cells were stressed by the exposure to light: $\mathrm{F}_{\mathrm{v}} / \mathrm{F}_{\mathrm{m}}=\left(\mathrm{F}_{\mathrm{m}}-\mathrm{F}_{0}\right) / \mathrm{F}_{\mathrm{m}}$, where $\mathrm{F}_{\mathrm{m}}$ is the maximum fluorescence and $\mathrm{F}_{0}$ is the minimum fluorescence.

BPV electrical measurement. Crocodile clips and copper wire were used to connect the anode and cathode of the BPV devices to the external circuit. Polarization curves (voltage vs current density) were constructed by applying external resistance stepping technique, where the external resistance was decreased every $10 \mathrm{~min}$ with corresponding voltage measurement using a multimeter (Agilent U1251B). The current is derived using Ohm's Law. Different range of external resistance were tested to find suitable resistance with respective of voltage drop across the resistor. The sequence of external resistance was $10 \mathrm{M} \Omega, 5.6 \mathrm{M} \Omega, 2 \mathrm{M} \Omega, 560 \mathrm{~K} \Omega, 240 \mathrm{~K} \Omega, 62 \mathrm{~K} \Omega$, $22 \mathrm{~K} \Omega, 9.1 \mathrm{~K} \Omega, 2.7 \mathrm{~K} \Omega$ and $1.1 \mathrm{~K} \Omega$. The maximum current density and power density are evaluated from the polarization curve. Each measurement was repeated in triplicate. All statistical analyses were performed using the Statistica 8 program.

Absorption spectrum of pigments from Chlorella UMACC 313-measured and simulated. Pigments (chlorophylls and carotenoids) were extracted from an exponential culture of Chlorella UMACC 313. The pigment extract $(1 \mathrm{~mL}$ ) was subjected to scanning from 350 to $700 \mathrm{~nm}$ at intervals of $20 \mathrm{~nm}$, using the Shimadzu UV 1800 spectrophotometer, to generate the absorption spectrum. This measured absorption spectrum is simulated in the light provided by a PLA with 16 LEDs (Telelumen LLC, Saratoga, CA, US).

Received: 22 April 2020; Accepted: 4 September 2020

Published online: 30 September 2020

\section{References}

1. Tanneru, H. K., Kuruvinashetti, K., Pillay, P., Rengaswamy, R. \& Packirisamy, M. Micro photosynthetic power cells. J. Electrochem. Soc. 166(9), B3012-B3016 (2011).

2. Ng, F. L. et al. Reduced graphene oxide anodes for potential application in algae biophotovoltaic platforms. Sci. Rep. 4, 7562 (2014).

3. Ng, F. L. et al. Algal biophotovoltaic (BPV) devices - Surface potential studies. ACS Sustain. Chem. Eng. https://doi.org/10.1021/ acssuschemeng.0c02831 (2020).

4. Bombelli, P. et al. Harnessing solar energy by bio-photovoltaic (BPV) devices. Commun. Agric. Appl. Biol. Sci. 76, 89-91 (2011).

5. Jia, X. et al. Carbon paper electrode modified with $\mathrm{TiO} 2$ nanowires enhancement bioelectricity generation in microbial fuel cell. Synth. Methods 215, 70-175 (2016).

6. Bu, L. et al. Surface engineering of hierarchical platinum-cobalt nanowires for efficient electrocatalysis. Nat. Commun. 7, 11850 (2016).

7. Kodali, M. et al. Enhancement of microbial fuel cell performance by introducing a nano-composite cathode catalyst. Electrochim. Acta 264, 56-64 (2018).

8. Karthikeyan, C. et al. 3D Flower-like $\mathrm{FeWO} 4 / \mathrm{CeO} 2$ hierarchical architectures on $\mathrm{GGO}$ for durable and high performance microalgae biophotovoltaic fuel cells. Appl. Biochem. Biotechnol. https://doi.org/10.1007/s12010-020-03352-4 (2020).

9. Ramanan, A. V., Pakirisamy, M. \& Williamson, S. S. Advanced fabrication, modeling, and testing of a microphotosynthetic electrochemical cell for energy harvesting applications. IEEE Trans. Power Electron. 30(3), 1275-1285 (2015).

10. Ng, F. L., Phang, S. M., Periasamy, V., Yunus, K. \& Fisher, A. C. Evaluation of algal biofilms on indium tin oxide (ITO) for use in biophotovoltaic platforms based on photosynthetic performance. PLoS ONE 9(5), e97643 (2014).

11. Ng, F. L., Phang, S. M., Periasamy, V., Yunus, K. \& Fisher, A. C. Enhancement of power output by using alginate immobilized algae in biophotovoltaic devices. Sci. Rep. 7, 16237 (2017).

12. Ng, F. L. et al. Algal biophotovoltaic (BPV) device for generation of bioelectricity using Synechococcus elongatus (Cyanophyta). J. Appl. Phycol. 30(6), 2981-2988 (2018).

13. El-Khoulya, M. E., Mohsnawy, E. E. \& Fukuzumi, S. Solar energy conversion: From natural to artificial photosynthesis. J. Photochem. Photobiol. C. 31, 36-83 (2017).

14. Maxwell, K. \& Johnson, N. Chlorophyll fluorescence- A practical guide. J. Exp. Bot. 51(345), 659-668 (2000).

15. Barbera, E., Sforza, E., Guidobaldi, A., Di Carlo, A. \& Bertucco, A. Integration of dye-sensitized solar cells (DSC) on photobioreactors for improved photoconversion efficiency in microalgal cultivation. Renew. Energy. 109, 13-21 (2017).

16. Khoeyi, Z. A., Seyfabadi, J. \& Ramezanpour, Z. Effect of light intensity and photoperiod on biomass and fatty acid composition of the microalgae, Chlorella vulgaris. Aquac. Int. 20(1), 41-49 (2012).

17. Smith, B. M. et al. Response of the photosynthetic apparatus in Dunaliella salina (green algae) to irradiance stress. Plant Physiol. 93, 1433-1440 (1990).

18. Carvalho, A. P., Silva, S. O., Baptista, J. M. \& Malcata, F. X. Light requirements in microalgal photobioreactors: An overview of biophotonic aspects. App. Microbial. Biotechnol. 89, 1275-1288 (2011).

19. Ge, Z., Zhang, H., Zhang, Y., Yan., C. \& Zhao, Y. Purifying synthetic high-strength wastewater by microalgae Chlorella vulgaris under various light emitting diode wavelengths and intensities. J. Environ. Health Sci. 11, 8 (2013).

20. Schulze, P. S. C., Barreira, L. A., Pereira, H. G. C., Perales, J. A. \& Varela, J. C. S. Light emitting diodes (LEDs) applied to microalgal production. Trends Biotechnol. 32(8), 422-430 (2014).

21. Teo, C. L. et al. Enhancing growth and lipid production of marine microalgae for biodiesel production via the use of different LED wavelengths. Bioresour. Technol. 162, 38-44 (2014).

22. Sforza, E., Barbera, E. \& Bertuccon, A. Improving the photoconversion efficiency: An integrated photovoltaic-photobioreactor system for microalgal cultivation. Algal Res. 10, 202-209 (2015).

23. Das, P., Wang, L., Aziz, S. S. \& Obbard, J. P. Enhanced algae growth in both phototrophic and mixotrophic culture under blue light. Bioresour. Technol. 102(4), 3883-3887 (2011).

24. Mohsenpour, S. F. \& Willoughby, N. Luminescent photobioreactor design for improved algal growth and photosynthetic pigment production through spectral conversion of light. Bioresour. Technol. 142, 147-153 (2013).

25. Phang, S.M. \& Chu, W.L. Catalogue of Strains, University of Malaya Algae Culture Collection (UMACC). (Institute of Postgraduate Studies and Research, 1999).

26. De-Bashan, L. E. \& Bashan, Y. Joint immobilization of plant growth-promoting bacteria and green microalgae in alginate beads as an experimental model for studying plant-bacterium interactions. Appl. Environ. Microbiol. 74(21), 6797-6802 (2008).

27. Kim, T.H., Lee, Y.H., Han, S.H. \& Hwang, S.J. The effects of wavelength and wavelength mixing ratios on microalgae growth and nitrogen, phosphorus removal using Scenedesmus sp. for wastewater treatment. Bioresour. Technol. 130, 75-80 (2013).

28. Garrido, I. M. Microalgae immobilization: Current techniques and uses. Bioresour. Technol. 99, 3949-3964 (2008). 
29. Faraloni, C. \& Torzillo, G. Synthesis of antioxidant carotenoids in microalgae. in Response to Physiological Stress, Carotenoids. (ed. Cvetkovic, D.) 143-157 (InTech, 2017).

30. Morales, M. Sánchez, L. \& Revah, S. The impact of environmental factors on carbon dioxide fixation by microalgae. FEMS Microbiol. Lett. 365(3), fnx262 (2018).

31. DiMario, R. J., Machingura, M. C., Waldrop, G. L. \& Moroney, J. V. The many types of carbonic anhydrases in photosynthetic organisms. Plant Sci. 268, 11-17 (2018).

32. Sayre, R. Microalgae: The potential for carbon capture. Bioscience 60(9), 722-727 (2010).

33. Blankenship, R. E. et al. Comparing photosynthetic and photovoltaic efficiencies and recognizing the potential for improvement. Science 332, 805-809 (2011).

34. Eggert, A., Häubner, N., Klausch, S. \& Schumann, R. Quantification of algal biofilms colonising building materials: Chlorophyll a measured by PAM-fluorometry as a biomass parameter. Biofouling 22(1/2), 79-90 (2006).

35. Ramanna, L., Rawat, I. \& Bux, F. Light enhancement strategies improve microalgal biomass productivity. Renew. Sustain. Energ. Rev. 80, 765-773 (2017).

36. Li, J. H., Bin, H., Lin, J., Chen, F. \& Miao, X. Effects of light-emitting diodes under capped daily energy consumption with combinations of electric power and photoperiod on cultivation of Chlorella pyrenoidosa. Bioresour. Technol. 205, 126-132 (2016).

37. Levlin, E. Conductivity measurements for controlling municipal waste-water treatment. in Proceedings of a Polish-Swedish-Ukrainian Seminar 51-62 (2010).

38. Thong, C. H. et al. Effect of different irradiance levels on bioelectricity generation from algal biophotovoltaic (BPV) devices. Energy Sci. Eng. 7(5), 2086-2097 (2019).

39. Strickland, J.D.H. \& Parsons, T.R. A Practical Handbook of Seawater Analysis. (Fisheries Research Board of Canada, 1968).

40. Takaichi, S. Carotenoids in algae: Distributions, biosyntheses and functions. Mar. Drugs. 9, 1101-1118 (2011).

41. Eaton, A.D., Clesceri, L.S., Greenberg, A.E. \& Franson, M.A.H. Standard Methods for the Examination of Water and Wastewater. (American Public Health Association, 1998).

42. Guillard, R.R.L. Division rates. in Handbook of Phycological Methods: Culture Methods and Growth Measurement (ed. Stein, J.R.) 2289-2311 (Cambridge University Press, 1973).

43. Fulke, A. B. et al. Bio-mitigation of $\mathrm{COf}_{2}$ calcite formation and simultaneous biodiesel precursors production using Chlorella sp. Bioresour. Technol. 101(21), 8473-8476 (2010).

44. Perkins, R. G. et al. Responses of microphytobenthos to light: Primary production and carbohydrate allocation over an emersion period. Mar. Ecol. Prog. Ser. 223, 101-112 (2001).

45. Platt, T., Gallegos, C. L. \& Harrison, W. G. Photoinhibition of photosynthesis in natural assemblages of marine phytoplankton. J. Mar. Res. 38, 103-111 (1980).

\section{Acknowledgements}

This work was supported by Higher Institution Centre of Excellence (HICoE) Fund, Ministry of Education: Air ocean and land interaction (IOES-2014F); IOES UMCoE RU Grant (RU009B-2018, PUP 2019); Newton Prize 2017 (IF008-2018), and UM Algae Grant (GA003-2012).

\section{Author contributions}

F.N., S.P., B.L. and V.K. conceived the research and designed the experiments. F.N., C.T. and K.C. performed the experiments, analysed and interpreted the data with the support of V.P., K.Y. and A.F. F.N. wrote the article. S.P., B.L., V.K., K.C. and G.G. edited the manuscript. All authors read and approved the final manuscript. S.P. (phang@um.edu.my) take responsibility for the integrity of the research and manuscript.

\section{Competing interests}

The authors declare no competing interests.

\section{Additional information}

Correspondence and requests for materials should be addressed to S.-M.P.

Reprints and permissions information is available at www.nature.com/reprints.

Publisher's note Springer Nature remains neutral with regard to jurisdictional claims in published maps and institutional affiliations.

(c) Open Access This article is licensed under a Creative Commons Attribution 4.0 International

License, which permits use, sharing, adaptation, distribution and reproduction in any medium or format, as long as you give appropriate credit to the original author(s) and the source, provide a link to the Creative Commons licence, and indicate if changes were made. The images or other third party material in this article are included in the article's Creative Commons licence, unless indicated otherwise in a credit line to the material. If material is not included in the article's Creative Commons licence and your intended use is not permitted by statutory regulation or exceeds the permitted use, you will need to obtain permission directly from the copyright holder. To view a copy of this licence, visit http://creativecommons.org/licenses/by/4.0/.

(c) The Author(s) 2020 